\title{
Enhancement The Social Learning Result Throught The Use of Learning Video Media
}

\section{Septiana Nurvitasari}

Universitas Sebelas Maret

Septivita43@gmail.com

\section{Article History}

received 30/4/2021

\begin{abstract}
This study aims to determine the improvement of social studies learning outcomes on cultural diversity material through the use of video media for fourth grade students of SDN 01 Papahan in 2020/2021. The low value of learning outcomes and the lack of variation in the use of learning media are the reasons for conducting research. The research is a type of classroom action research which includes planning, implementation, observation and reflection. Data were taken through tests, documentation and observation with 28 students as respondents. The success indicator is $80 \%$ KKM 70. Learning outcomes in the pre-cycle only 9 students or $32.14 \%$ who complete the KKM while those who do not complete are 19 students or $67.86 \%$. In the first cycle Completed: 17 students or $60.71 \%$, then 11 students who did not complete the KKM or $39.29 \%$ did not complete. Cycle II learning outcomes Completed KKM as many as 23 students or $82.14 \%$, while those who did not complete KKM were 5 students or $17.86 \%$. Based on the increase in each cycle, this study concludes that the use of instructional video media can improve social studies learning outcomes in the fourth grade material for cultural diversity at SDN 01 Papahan.
\end{abstract}

Keywords: Learning Media, Video, Social Learning

\section{Abstrak}

Penelitian bertujuan untuk mengetahui peningkatan hasil belajar IPS pada materi keberagaman budaya melalui penggunaan media video pada siswa kelas IV SDN 01 Papahan tahun 2020/2021. Rendahnya nilai hasil belajar dan kurangnya variasi dalam penggunaan media pembelajaran menjadi alasan melakukan penelitian. Penelitian termasuk jenis penelitian tindakan kelas yang meliputi perencanaan, pelaksanaan, observasi dan refleksi. Data diambil melalui tes, dokumentasi dan observasi dengan responen sebanyak 28 siswa. Indikator keberhasil $80 \%$ KKM 70. Hasil belajar pada pra siklus hanya 9 siswa atau 32,14\% yang tuntas KKM sedangkan yang tidak tuntas ada 19 siswa atau 67,86\%. Pada siklus I Tuntas:17 siswa atau $60,71 \%$, kemudian yang tidak tuntas KKM sejumlah 11 siswa atau $39,29 \%$. Siklus II hasil belajar Tuntas KKM sejumlah 23 siswa atau sejumlah $82,14 \%$, sedangkan yang tidak tuntas KKM sebanyak 5 siswa atau $17,86 \%$. Berdasarkan peningkatan pada setiap siklus, maka penelitian ini memberikan kesimpulan bahwa penggunaan media video pembelajaran dapat meningkatkan hasil belajar IPS pada materi keberagaman budaya kelas IV SDN 01 Papahan.

Kata kunci: Media Pembelajaran, Video, IPS 


\section{PENDAHULUAN}

Pendidikan pada dasarnya merupakan suatu proses komunikasi yang mengandung transformasi pengetahuan, ketrampilan serta nilai-nilai dalam kehidupan social yang berlangsung sepanjang hayat. Pendidikan menurut Ihsan (2008: 52) yaitu merupakan pengarahan dan bimbingan yang diberikan kepada anak untuk memperoleh kepribadian serta proses pendewasaan. Pengetahuan dan ketrampilan perlu dikembangkan untuk bekal pada jenjang Pendidikan selanjutnya, hal tersebut selaras dengan pendapat Adebayo dan Bello ( 2015: 94) "basic science prepare pupils to have solid foundation in science and builds them as future scientist" maksudnya, perlu mempersiapkan siswa dengan dasar ilmu pengetahuan sehingga dapat dikembangkan pada jenjang pendidikan selanjutnya. IImu Pengetahuan Sosial pada jenjang Sekolah Dasar menurut Sapriya (2012: 20) merupakan mata pelajaran yang berdiri sendiri sebagai integrasi dari ilmu sosial, humaniora dan masalah sosial kehidupan. Pembelajaran IPS memiliki peranan penting untuk meningkatkan mutu pendidikan khususnya dalam meningkatkan generasi yang berkualitas, yaitu manusia yang humanis, simpati, kreatif dan logis.

Menurut Sardiman A.M (2017: 28-29) menyatakan hasil belajar merupakan hasil pencapaian dari tujuan belajar yang dilakukan. Hasil belajar merupakan suatu proses yang dapat dilakukan seseorang setelah melakukan berbagai kegiatan belajar, hasil belajar dapat meliputi ranah kognitif, efektif maupun psikomotor yang diambil dari data penilaian oleh guru (R.Aliyah, Puteri \& Kurniawati, 2017: 45). Puncak dari proses belajar merupakan hasil belajar yang dapat menghasilkan perubahan baik dari segi pengetahuan, sikap, dan ketrampilan yang saling berkaitan dan dinamis sehingga dapat diukur serta diamati. Menurut Darmadi (2017: 27) untuk menyatakan bahwa suatu proses belajat dikatakan berhasil apabila setiap pendidik dan peserta didik memiliki kesamaan pemahaman. Selain itu, telah berhasil dalam mencapai tiga aspek kognitif, afektif, dan psikomotorik. Berdasarkan ketiga ranah tersebut, ranah kognitif yang paling banyak dinilai oleh guru karena berhubungan dengan kemampuan peserta didik dalam memahami dan menguasai muatan isi bahan pembelajaran. Untuk meningkatkan hasil belajar diperlukan perantara supaya materi dapat dipahami peserta didik dengan mudah, perantara yang dapat digunakan yaitu berupa media video pembelajaran.

Media pembelajaran merupakan komponen yang tidak dapat terpisahkan dari proses pembelajaran, hal tersebut selaras dengan pendapat Andriani (2019: 23) kegiatan belajar mengajar dapat berlangsung dengan baik apabila ada komponen integral berupa media. Menurut Rayandra Asyhar (2012: 44-45) media pembelajaran dikelompokkan menjadi empat jenis yaitu media visual, media audio, media audio visual dan multimedia. Media pembelajaran dapat membantu guru dalam proses belajar untuk memotivasi dan meningkatkan pemahaman siswa, yaitu berupa video. Menurut Joenady (2019: 39) media video merupakan seperangkat komponen yang dapat menampilkan gambar dan suara dalam waktu bersamaan. Penggunaan media video sangat menarik karena dapat menampilkan kejadian dimasa lampau khususnya sejarah, dapat mengambarkan berada ditempat yang sulit terjangkau misalnya Ketika terjadi gejala alam sehingga diharapkan dapat meningkatkan hasil belajar siswa.

Fakta yang ditemui dilapangan yaitu, masih banyak peserta didik yang merasa bosan dan menggangap sulit muatan pelajaran IPS selain itu guru belum menggunakan media yang menarik hanya berupa textbook. Berdasarkan hasil wawancara dengan guru kelas IV SDN 01 Papahan, hasil belajar IPS tergolong rendah khususnya pada materi keragaman budaya. Hasil belajar masih tergolong rendah , adapun KKM yang diterapkan sekolah yaitu 70 . Hal ini dapat terlihat dari jumlah siswa sebanyak 28, siswa yang nilainya tuntas KKM hanya 9 siswa dengan presentase $32,14 \%$ dan yang nilainya tidak tuntas sebesar 19 siswa dengan presentase sebesar $67,86 \%$. 
Pembelajaran IPS merupakan muatan pembelajaran yang tidak hanya dapat mengandalkan buku bacaan saja, tetapi juga diperlukan penggunaan media sehingga dapat memberikan gambaran yang lebih jelas kepada siswa menjadi lebih konkret. Media video termasuk media yang menarik bagi siswa sehingga dapat meningkatkan hasil belajar. Pembelajaran yang semula membosankan dan kurang variatif beralih menjadi pembelajaran yang menyenangkan dan inovatif dengan penggunaan media video pembelajaran. Sehingga siswa akan memiliki semangat dan motivasi dalam belajar. Hal ini selaras dengan pendapat Purwanto (2013: 11) motivasi belajar merupakan dorongan yang disengaja supaya dapat mempengaruhi seseorang untuk tergerak hatinya agar melakukan suatu tindakan demi mencapai hasil belajar. Hal tersebut juga telah berhasil dilakukan oleh peneliti terdahulu Luci Tri Wijayanti (2013) melakukan penelitian "Peningkatan Kualitas Pembelajaran IPS melalui Model Cooperative Script dengan media Audio Visual pada Siswa kelas V SDN Mangkangkulon 01 Kota Semarang". Pada hasil penelitian tersebut menunjukkan ketrampilan guru dalam mengajar termasuk dalam kategori baik dari siklus I sampai siklus III, sedangkan untuk hasil belajar pada siklus I ketuntasan mencapai $66 \%$, siklus II diperoleh $73 \%$, dan pada siklus III diperoleh $83 \%$. Tujuan dari penelitian ini adalah untuk mengetahui peningkatan hasil belajar IPS melalui penggunaan media video pembelajaran.

Berdasarkan latar belakang masalah yang telah diuraikan di atas, supaya dapat meningkatkan hasil belajar IPS oleh karena itu perlu dilakukan Penelitian Tindakan Kelas.Peneliti tertarik untuk mengadakan penelitian pada siswa kelas IV SDN 01 Papahan tahun Ajaran 2020/2021 dalam upaya meningkatkan hasil belajar IPS melalui penggunaan media video.

\section{METODE}

Penelitian ini merupakan penelitian tindakan kelas (PTK) karena berupaya memecahkan permasalahan yang ada di kelas serta meningkatkan hasil belajar IPS. Tindakan yang akan dilakukkan dalam penelitian ini mencakup empat tahap yang meliputi kegiatan sebagai berikut; rencana tindakan, pelaksanaan tindakan, pengamatan/observasi dan refleksi. Hasil evaluasi kemudian dianalisis untuk menentukan langkah-langkah perbaikan apa yang bisa ditempuh, sehingga didapatkan suatu solusi untuk semua permasalahan yang dialami oleh guru dan siswa dalam proses. Penelitian dilaksanakan di kelas IV SDN 01 Papahan Kecamatan Tasikmadu Kabupaten Karanganyar semester II tahun pelajaran 2020/2021 dengan subjek 28 anak.

Metode yang digunakan dalam penelitian ini yaitu menggunakan; dokumen, yaitu peneliti mengadakan pre tes kemampuan belajar IPS sebelum diadakan tindakan. Teknik tes, untuk membandingkan hasil belajar sebelum dan sesudah tindakan. Observasi, dilakukan selama proses penggunaan media video dalam pembelajaran berlangsung untuk hasil belajar IPS.

Teknik analisis data dalam penelitian ini dilakukan dengan analisis interaktif, meliputi tahap reduksi data, tahap penyajian data dan tahap verifikasi data dan penarikan kesimpulan. Analisis data dilakukan setiap selesai satu siklus baik hasil tes maupun hasil observasi yang dilaksanakan dibandingkan dengan siklus sebelumnya.

\section{HASIL DAN PEMBAHASAN}

Penelitian ini dilakukan dalam 2 siklus yaitu siklus I dan siklus II. Sebelum masuk ke tindakan, peneliti terlebih dahulu melakukan pra siklus. Berdasarkan data hasil tes pra siklus ditemukan rendahnya hasil belajar IPS dengan siswa yang tuntas KKM hanya 9 siswa atau 32,14\% sedangkan siswa yang tidak tuntas KKM terdapat 19 siswa atau $67,86 \%$ beberapa hal yang menyebabkan rendahnya belajar yaitu karena kurangnya inovasi media pembelajaran. Peneliti menggunakan media pembelajaran 
yang inovatif berupa video pembelajaran inovatif untuk meningkatkan hasil belajar IPS khususnya materi keberagaman budaya. Proses penelitian ini dilaksanakan dalam 2 siklus yang masing-masing siklus terdiri dari 4 tahapan, yaitu; (1) perencanaan tindakan; (2) pelaksanaan tindakan; (3) observasi dan interpretasi; dan (4) analisis dan refleksi tindakan dari siklus I sampai siklus II Berikut ini diuraikan deskripsi tiap siklus tersebut dapat diperoleh hasil sebagai berikut: Siklus I Tuntas sebanyak 17 siswa atau $60,71 \%$, kemudian yang tidak tuntas KKM sejumlah 11 siswa atau 39,29\%. Siklus II hasil belajar Tuntas KKM sejumlah 23 siswa atau sejumlah 82,14\%, sedangkan yang tidak tuntas KKM sebanyak 5 siswa atau 17,86\%. Berikut ini sajian tabel hasil belajar siswa kelas IV SDN 01 Papahan 2020/2021.

Tabel Hasil Belajar Siswa Pra Siklus ,Siklus I dan Siklus II

\begin{tabular}{lccc}
\hline Kriteria KKM 70 & \multicolumn{3}{c}{ Kegiatan Belajar pada: } \\
\hline & Pra siklus & Siklus I & $\begin{array}{c}\text { Siklus } \\
\text { II }\end{array}$ \\
\hline Tuntas & 9 & 17 & 23 \\
\hline Tidak Tuntas & 19 & 11 & 5 \\
\hline Tuntas (\%) & $32,14 \%$ & $60,71 \%$ & $82,14 \%$ \\
\hline Tidak Tuntas (\%) & $67,86 \%$ & $39,29 \%$ & $17,86 \%$ \\
\hline
\end{tabular}

Berdasarkan hasil pelaksanaan pada siklus I dan II dapat dinyatakan bahwa terjadi peningkatan motivasi hasil belajar IPS materi keberagaman budaya di Indonesia melalui penggunaan media video. Siswa terlihat antusias dan bersemangat. Hal ini dapat terlihat siswa antusias dan semangat saat merespon pembelajaran dari guru. Pada setiap proses pembelajaran terjadi umpan balik, guru selalu memberikan pertanyaan-pertanyaan baik tes maupun nontes kepada siswa mengenai materi pembelajaran melalui zoom meeting.

Penggunaan media video inovatif pada pembelajaran khususnya materi keragaman budaya muatan pelajaran IPS memiliki peranan penting supaya siswa semangat dalam belajar sehingga hasil belajar IPS dapat meningkat. Media video sebagai suatu kemajuan teknologi telah banyak memberikan pengaruh positif dan kemajuan bagi manusia dan kebudayaan, melalui video siswatidak lagi sulit dalam menemukan berbagai informasi. Penggunaan media video selain inovatif, efektif dan efisien juga memberikan pengaruh positif kepada siswa, khususnya dalam aspek kognitif terhadap hasil belajar siswa. Media video pembelajaran yang dikemas secara menyenangkan akan membuat proses belajar mengajar berjalan menyenangkan, apabila proses belajar mengajar menyenangkan maka akan terjadi peningkatan semangat belajar siswa. Siswa akan bersemangat dalam mengerjakan tugas-tugas yang diberikan guru dan lebih mudah mengingat materi yang disampaikan oleh guru. Kesanggupan siswa dan minat belajarnya setelah menggunakan media video, telah berhasil membuat siswa menerima materi dengan baik serta memperhatikan materi yang disampaikan guru.

Hal ini juga membuktikan bahwa, kelas yang menggunakan medio video dapat meningkatkan hasil belajar IPS materi keberagaman budaya pada siswa kelas IV SD N 01 Papahan tahun 2020/2021. Oleh karena itu, penelitian yang dilakukan dengan menggunakan media video pada siswa kelas IV SDN 01 Papahan dinyatakan berhasil sehingga penelitian dapat diakhiri dan tidak perlu melanjutkan pada siklus berikutnya karena sudah mencapai indikator keberhasilan. 


\section{SIMPULAN}

Berdasarkan data hasil penelitian dan tindakan yang telah dilakukan selam 2 siklus di kelas IV SDN 01 Papahan telah berhasil membuktikan bahwa penggunaan media video dapat meningkatkan hasil belajar siswa kelas IV SDN 01 Papahan dalam muatan pelajaran IPS khususnya materi keberagaman budaya. Peningkatan hasil belajar dapat dibuktikan dengan adanya peningkatan ketuntasan KKM pada setiap siklusnya, pada pra siklus hanya 9 siswa atau $32,14 \%$, kemudian pada siklus I sejumlah 17 siswa atau $60,71 \%$ selanjutnya pada siklus II sejumlah 23 siswa atau $82,4 \%$ telah tuntas KKM. Dengan demikian, penelitian telah berhasil mencapai indicator keberhasilan sebesar $80 \%$. Oleh karena itu, proses penelitisan penggunaan media video untuk meningkatkan hasil belajar IPS di SDN 01 Papahan tahun 2020/2021 dapat dikatakan telah berhasil.

Implikasi dari penelitian ini, yaitu pentingnya guru menggunakan media video pembelajaran yang lebih kreatif dan inovatif, yaitu berupa media video pembelajaran yang memudahkan siswa dalam memahami materi pembelajaran. Penggunaan media video dapat digunakan sebagai alternatif peningkatan hasil belajar.

\section{DAFTAR PUSTAKA}

Adebayo, Famakinwa dan Bello Theodora Olufunke. "Generative and Predict Observe Explain Instructional Strategies: Towards Enhancing Basic Science Practical Skills of Lower Primary School Pupils". Dalam Jurnal International Journal of Elementary Education, vol. 4, no. 4, September 2015, halaman: 94.

Andriani. (2019). Pengembangan Media Pembelajaran Video Animasi Untuk Meningkatkan Kemampuan Berpikir Tingkat Tinggi dan Hasil Belajar Di Sekolah Dasar. Jurnal Teknologi Pendidikan dan Pembelajaran, 6 (1).

Aliyyah, R. Puteri, \& Kurniawati A. (2017). Pengaruh Kemandirian Belajar Terhadap Hasil Belajar IPA. Jurnal Sosial Humaniora, 8(2).

Asyhar, Rayandra. 2012. Kreatif Mengembangkan Media Pembelajaran. Jakarta: Referensi

Darmadi. (2017). Pengembangan Model dan Metode Pembelajaran dalam Dinamika Belajar Siswa. Yoghyakarta: Deepublish Pubblisher

Ihsan, Fuad. 2008. Dasar-Dasar Kependidikan. Jakarta: Referensi

Joenaidy, A. M. (2019). Konsep dan Strategi Pembelajaran di Era Revolusi 4.0. Yogyakarta: Laksana

Purwanto, M. Ngalim. 2013. Psikologi Pendidikan. Bandung: PT Remaja Rosda Karya

Sapriya. 2012. Pendidikan IPS. Bandung: PT Remaja Rosdakarya

Sardiman. 2017. Interaksi dan Motivasi Belajar Mengajar. Jakarta: Raja Grafindo Persada 